\title{
INFLUENCE OF ENVIRONMENTAL FACTORS ON THE EVOLUTION OF ROMANIAN PUBLIC ACCOUNTING
}

\author{
Cristina Silvia NISTOR ${ }^{1}$, Adela DEACONU ${ }^{2}$, Codruta MARE ${ }^{3}$ \\ Babes-Bolyai University, Faculty of Economics and Business Administration, \\ Cluj-Napoca, Romania \\ E-mails: ${ }^{1}$ cristina.nistor@econ.ubbcluj.ro (corresponding author); \\ 2adela.deaconu@econ.ubbcluj.ro; ${ }^{3}$ codruta.mare@econ.ubbcluj.ro
}

Received 12 February 2013; accepted 09 May 2013

\begin{abstract}
Using a historiography approach on public accounting, this research add value to this knowledge providing a customization of the environmental influential factors for an emergent context, the Romanian one, in specific historical phases between 1831 and 2011. The critical-interpretative picture of an extended period of 180 years is complemented by an empirical approach, an original issue in accounting history. Empirical findings based on cluster analysis confirm the existence of six influential factor groups and the intergroup interdependency and provides a fundamental explanation for the effect of factors' combination. The political system has an influence over the economic system, which impacts accounting development, the reporting and disclosure system required by users. The connection between legal and economic factors decided the type of accounting legal system. Socio-cultural factors affected the accounting policies and decided accountancy's progress, closely linked to the educational factor whose strong influence impacted the accounting theory and practice. All this results are a benchmark for other emergent countries.
\end{abstract}

Keywords: public accounting, accounting history, emergent country, environmental factors, cluster analysis, case study.

JEL Classification: M10, M41, M48.

\section{Introduction}

In international accounting research, environmental influence was presented as the key to understanding one country's accounting system (e.g. Zhang 2005). Hoque and Hopper (1994) argue that solely individual accounting system, without any connection to the influence of environmental factors, is not sufficient to accurately reflect its content. Also, public accounting cannot be viewed isolated from the environment in which it manifests expressed at a particular point in space or time (Carnegie, Napier 2002), observing the economic, political, socio-cultural, educational and professional factors that manifest over time. The question that rises is: Which of these factors has a greater influential power? Or which is the interdependency of these factors? The answer may be different from one phase in the accounting system's evolution to another, depending on the national and international context. 
The purpose of this research is to determine the power of various environmental factors to generate changes in public accounting according to a framework which we proposed based on Zang (2005), Choi and Mueller (1984), Nobes (1984), Gray (1988), Radebaugh and Gray (1997) propositions. Using a historiography approach we aimed to identify influential factor groups which were divided in elements and sub-elements in order to form clusters important in the interpretation of public accounting evolution. To reveal the framework effectiveness, our research applies it in a case study i.e. the Romanian context. An emergent country in the Central and Eastern European (CEE) area, member of the European Union (EU) since 2007, Romania finds itself in a political, economic, social and cultural network where international factors intertwine. Research of influential factors in an emergent country such as Romania is justified by the fact that the change of the accounting system in these countries often overlaps with the adoption of the model in certain developed countries such as western capitalist countries (Nachescu 2010), or with the influence of dominant powers (Schroll 1995) (such as the soviet accounting model).

The study of Romanian public accounting covers the period between the occurrence of public accounting in Romania (year 1831) and present (year 2011). We resorted to periodization which can be used to emphasize the alleged deviations of present practices and institutions, to highlight the differences between different eras, the historical phases being based on the Romanian public accounting literature (Calu 2005; Nistor et al. 2008; Deaconu et al. 2009).

The present research is justified by a gap in the literature on the applicability of influential factors for public accounting, as well as the lack of studies that examine the impact of these factors in the context of emerging countries, and particularly European countries. In this spirit we mention few papers, for countries as Albania (Kajsiu 2010) or Egypt (Farag et al. 2004). However, most of these studies are rather descriptive compared to our research that fundaments in an empirical manner the effect of influential factors and addresses a much wider historical period of 180 years.

Based on the theoretical studies on public accounting history and on the description of influential factors of the public accounting system (section 1), according to the historical stages in the Romanian public accounting system, this study presents the former in the Romanian context (section 2). The empirical section of the study clusters the analyzed influential factors according to the historical period taken into consideration (section 3 ).

\section{Accounting environmental factors}

A large number of studies identified and explained some possible causes of the accounting systems diversity, in the pursuit to facilitate communication between countries (Mueller 1967; Choi, Mueller 1984; Nobes 1984; Gray 1988; Radebaugh, Gray 1997). In the late 1960s theoretical and empirical researches attempted to explain accounting systems in different countries depending on a number of factors (Zhang 2005). One universal accounting language is more and more desired. Subsequent to the delimitation of accounting systems according to their particularities (Nair, Frank 1980; Nobes 1998), the idea of accounting harmonization and convergence appeared (Alexander, Archer 
2001; Bellanca, Vandernoot 2013). Puxty et al. (1987: 275) argued that 'the institutions and processes of accounting regulation in different countries cannot be understood independently of the historical and political-economic context of their emergence and development'.

The identification of the factors of influence is the privilege of international accounting and represents the basis of classification and hierarchy of the accounting systems. Two main forms of approaching influential environmental factors are found in the international literature. So, through a deductive approach, political, economic, cultural, legal and fiscal factors are identified as the basis of the accounting systems' development (Mueller 1967; Choi, Mueller 1984; Nobes, Parker 1985; Gray 1988). Through an inductive approach, the differences and similarities between certain accounting systems are tested, operating a classification of the influential factors (Frank 1979; Nair, Frank 1980).

The theoretical base of this paper is represented by the synthesis drawn by Zang (2005), and also four other studies (Choi, Mueller 1984; Nobes 1984; Radebaugh, Gray 1997; Gray 1988). The applicability of these studies in the public sector is based on the recognition in the international literature of the influential factors' universality (e.g. Evans, Patton 1987; Cheng 1992; Laswad et al. 2005). Choi and Mueller (1984) start from the idea that accounting development is triggered by non-accounting factors such as political, legal, economic, cultural and professional factors. Nobes (1984) goes forward, laying stress on the particularities of micro and macroeconomic factors. Radebaugh and Gray (1997) underline the importance of environmental analysis and cultural relativism to explain and understand differences in the way business operates in different countries and accounting resembles international business. Gray (1988) connects the cultural factor with accounting and integrates the international factor in the area of influential factors. Table 1 reveals the influential factors identified by these studies.

Table 1. Accounting influential factors

\begin{tabular}{|c|c|c|c|c|}
\hline $\begin{array}{l}\text { Authors } \\
\text { Factors }\end{array}$ & $\begin{array}{c}\text { Choi and Mueller } \\
\text { (1984) }\end{array}$ & $\begin{array}{l}\text { Nobes } \\
(1984)\end{array}$ & $\begin{array}{l}\text { Gray } \\
(1988)\end{array}$ & $\begin{array}{l}\text { Radebaugh and } \\
\text { Gray (1997) }\end{array}$ \\
\hline (1) Political & Political System & & & Political system \\
\hline (2) Legal & $\begin{array}{l}\text { Legal system } \\
\text { Legislative business } \\
\text { inference } \\
\text { Specific accounting } \\
\text { legislation }\end{array}$ & $\begin{array}{l}\text { Legal } \\
\text { system } \\
\text { Taxation }\end{array}$ & Legal system & $\begin{array}{l}\text { Taxation system } \\
\text { Legal system } \\
\text { Accounting } \\
\text { regulation }\end{array}$ \\
\hline (3) Economic & $\begin{array}{l}\text { Business ownership } \\
\text { Size of business firms } \\
\text { Sophistication of } \\
\text { business } \\
\text { Business innovations } \\
\text { Economic development }\end{array}$ & $\begin{array}{l}\text { Providers } \\
\text { of finance } \\
\text { Inflation }\end{array}$ & $\begin{array}{l}\text { Corporate } \\
\text { ownership } \\
\text { Capital markets } \\
\text { Economic trade } \\
\text { Investment }\end{array}$ & $\begin{array}{l}\text { Enterprise } \\
\text { ownership } \\
\text { Business activities } \\
\text { Source of finance } \\
\text { Capital market } \\
\text { development } \\
\text { Economic growth } \\
\text { Inflation rate }\end{array}$ \\
\hline
\end{tabular}


End of Table 1

\begin{tabular}{|c|c|c|c|c|}
\hline $\begin{array}{l}\text { Authors } \\
\text { Factors }\end{array}$ & $\begin{array}{c}\text { Choi and Mueller } \\
\text { (1984) }\end{array}$ & $\begin{array}{l}\text { Nobes } \\
(1984)\end{array}$ & $\begin{array}{l}\text { Gray } \\
(1988)\end{array}$ & $\begin{array}{l}\text { Radebaugh and } \\
\text { Gray (1997) }\end{array}$ \\
\hline (4) Cultural & Social climate & Culture & Social values & $\begin{array}{l}\text { Social climate } \\
\text { Culture factors }\end{array}$ \\
\hline (5) Education & Professional education & & Education & $\begin{array}{l}\text { Accounting } \\
\text { education }\end{array}$ \\
\hline (6) Profession & $\begin{array}{l}\text { Professional } \\
\text { organization }\end{array}$ & $\begin{array}{l}\text { Profession } \\
\text { theory }\end{array}$ & $\begin{array}{l}\text { Professional } \\
\text { associations }\end{array}$ & $\begin{array}{l}\text { Accounting } \\
\text { research }\end{array}$ \\
\hline (7) International & & & $\begin{array}{l}\text { Economic/ } \\
\text { political } \\
\text { interdependence } \\
\text { Foreign direct } \\
\text { investment } \\
\text { Multinational } \\
\text { corporate strategy } \\
\text { International } \\
\text { financial markets } \\
\text { International } \\
\text { regulatory } \\
\text { organization } \\
\text { Business and } \\
\text { finance services }\end{array}$ & $\begin{array}{l}\text { International } \\
\text { factors }\end{array}$ \\
\hline
\end{tabular}

(8) Others

Accidents

\section{The study premises}

\subsection{Landmarks of Romanian public accounting evolution}

In relation to the period under study (1831-present), there were a lot of extensive change processes in the political field, in the whole CEE, with implications on the social and economic spectrum (e.g. World War, the fall of the communist bloc, the adherence to the EU). Accounting is found in the middle of this transformation process.

Through an analysis of historical research regarding the Romanian public accounting (Demetrescu 1972; Nistor et al. 2008; Deaconu et al. 2009) in conjunction with the legal requirements and accounting rules, this research defines and describe seven historical phases. The periodization was based on major political events that had an impact on the public accounting from the point of view of adopted principles, objectives and specific financial reporting rules. In brief, the year 1831 is acknowledged as the starting point of public accounting (Demetrescu 1972; Rusu et al. 1991; Calu 2005) when the issue of the organic regulations triggers a distinct delimitation of state property, year included by some authors in the period between 1795 and 1930 (Evian 1946) or 1682-1908 (Calu 2005). The year 1859 is unanimously accepted (Demetrescu 1972; Rusu et al. 1991) as the start of change in the perception of public accounting as a strict regulatory framework was developed and social-economic and cultural-educational measures 
were imposed. The period 1944-1989 is unanimously accused of stopping a tradition in the middle of its formation, with a certain tendency towards internationalization of the Romanian accounting judgment. The reason lies in the limitation of the accounting approach strictly to the Marxist vision, the base of the communist accounting judgment.

We further analyze each phase identified according to specific elements of the public sector.

a) Phase 1 (1831-1858). In the European society the liberal doctrine specific to capitalism inspires the economic level, while the social level is inspired by the idea of liberty imposed by the ascending middle class and the need to erase the nobiliary privileges and replace them with new social relationships. By publishing the Organic Laws in 1831-1832, as a result of the Treaty of Adrianopole, the distinction between state properties and sovereign properties is required for the first time (Constantiniu 1997; Calu 2005). This document established the separation of powers' principle and favored the development of new economic relations.

b) Phase 2 (1859-1907). The unification of the Romanian Principalities (1859) marks the emergence of the first law of financial organization in Romania, by the coming into force of the Finance Regulation (1860) during the reign of Alexandru Ioan Cuza. Bistriceanu (1992) mentions that the first law on public accounting appeared in 1864 and provided the methods for the elaboration, adaptation and implementation of the state budget. In terms of terminology, the period of debut is considered 'budgetary accounting' in detriment to the concept of 'public accounting'. Proper records management and public funds impose specific legal framework. Certain administrative-financial laws appear in this context, for example: Direct Contributions Law (1871) regarding the establishment and collection of public revenues; or direct contributions Census Law (1877) defining in its content the revenue tracking methods, tax scale, and state prescription privileges.

c) Phase 3 (1908-1943). After the Unification of 1918, when the unified budget was presented, Nicolae Titulescu, the minister of finance at that time, proposed the Tax Reform Legislation for Romania inspired from the financial legislation of developed countries. Its main objectives were: the reduction of public expenses, the establishment of preventive control of public expenditure, the ordering of payment for material and personnel expenditures in 12 equal monthly installments, and the introduction of the income tax (Demetrescu 1972; Rusu et al. 1991; Constantiniu 1997). The year 1923 represents the emergence of a new law on direct contributions, a tax system based on modern principles. Around this time, the budget unification, the tax reform and the unification and standardization of public accounting are achieved. The year 1929 marks the emergence of the Public Accounting Law. This highlights the beginning of the consolidation of financial administration in Romania.

d) Phase 4 (1944-1988). After 1944 Romania aligned to a political and economic regime imposed by the Soviet Union, identified as the beginning of the communist period. The year 1947 marks the establishment of the Ministry of Industry and Commerce, which has the task to issue accurate accounting regulations. A first important issue was 
the development of a unified chart of accounts (including public institutions) based on Eugen Schmalenbach (1927) framework. From the point of view of accounting's organization and management, although double entry bookkeeping was stipulated as far back as 1929, only in 1970 with the issue of Cabinet Council Resolution no 1885 all institutions that managed material goods and money had to be organized in this manner. In the communist era, public accounting was known as budgetary accounting, being under the direct influence of the Soviet accounting system, based on the Marxist theory of value, with applications in central planning charge.

e) Phase 5 (1989-2001). At the domestic level, this period is characterized by a slow evolution of the public accounting system. The same chart of accounts has been used since its enactment in 1984, with only a slight update of timing requirements. The information contained in the financial statements was presented in a completely different form compared to the financial statements of economic entities. In exchange, the Romanian accounting system for economic entities has been reformed in response to needs and requirements of information users for harmonization with European Directives and International Accounting Standards (Pitulice 2013). This created many difficulties for both practitioners and users of accounting information.

f) Phase 6 (2002-2005). The year 2002 mark the moment when major changes are made which will ultimately determine the shift from a cash accounting system to an accrual accounting system. In this context, the objective of public accounting is enriched by including revenue and expenditure accounting, which reflects the collection of revenue and expenditure (cash basis) and general accounting based on the principle of finding the rights and obligations, which reflects the changes in the financial position and patrimonial surplus or deficit (accrual basis). In this period the development of the international accounting standards in the public sector (IPSAS) is envisaged. Accounting changes and internationalization process involves multiple efforts (Ezzamel, Xiao 2011; Aubert, Grudnitski 2011).

g) Phase 7 (2006-present). During this period no significant legislative changes occur and the effects of previous measures manifest more clearly. The public accounting system in Romania is recognized to have an accrual basis. The main features of the new public accounting system link it to the economic entities and consist in the harmonization of the chart of accounts, respectively of the financial statements structure and content (Albu et al. 2013).

\subsection{The framework and environmental factors identification}

The framework of this paper was developed starting from its objectives: to adjust the influential factors of an accounting system defined in the international literature to public accounting and to the Romanian context; to conduct an analysis of the factors considering two aspects: the individual power of influence of each factor within the factor group and within the time extent, and the interconnection between the elements and sub-elements of the factor groups (1) and the significance of the clusters established by combining the elements and sub-elements of the factor groups that influenced the evolution of the Romanian public accounting in the analyzed period (2). 
The factor groups taken into consideration in our study based on the analysis of the literature are political, legal, economic, social-cultural, educational and professional. We have particularized the influential factors identified in a longitudinal perspective developing the analysis for each factor and for each period after the analysis of the specific literature and our own classification in elements and sub-elements. The element 'political structure', part of political factors group (Bengtsson 2011), is an exception because its particularization in sub-elements was based on Gastil's (1978) approach, this being most suitable in the case of Romania.

Based on the review in Table 1 (Section 2) and on the historiography research dedicated to Romania for the period between 1831 and 2011 (Section 3.1), we have conducted a concise analysis of the main characteristics of the public accounting system and the specific regulations, revealed in Appendix. Besides the selected factors groups, Appendix presents for the defined historical phases the elements and sub-elements of influential factors and their occurrence, encoding 1 for occurrence and 0 for non-occurrence.

We did not consider in our framework international factors which are part of other element groups or sub-elements such as accidental factors which are difficult to analyze for such an extended period. The economic environment includes macro and micro aspects. As part of macroeconomic aspects we made a selection of three factors, measurable for the historical periods in question: the economic system type, the public or private ownership and the stage of economic development. In line with Rezaee (1998), the analyzed factors illustrate the complexity of entities in the studied historical phases, influenced directly by two elements fundamental for the microeconomic development's stage i.e. the competition policies and the financial sources. Cultural factors are not explicitly recognized in our framework, considering Mueller (1967) approach. These factors were subsumed within the social sphere (changes in lifestyle, forms of social protection, access to and quality of information).

\section{Analysis and results}

After dividing the factors on historical phases, we have proceeded in analyzing the interconnections that exist between them, with an emphasis on the influence they had upon the Romanian public accounting system.

As statistical research method, the cluster analysis has proved to be efficient for the purpose of our study. Usually, this method is used to group information in the database, while taking into account the whole set of interdependencies between the variables, regardless if they are exogenous or endogenous, no assumptions being made concerning the number of groups or group structure (Ungureanu, Ersoz 2010). Grouping is done on the basis of similarities of distances (dissimilarities) using the variable's value observed in each individual (Johnson, Wichern 1982). Hierarchical clustering is a subjective method in the sense that the distance used as a criterion in determining the optimum number of groups is not given by a standard formula. Instead, it is chosen by the analyst from the dendogram or from the agglomeration schedule, based on the "gaps" that appear on the horizontal axis. The goal of the analysis is to reduce a large number 
of variables to a smaller number of groups that can be more easily used further on. The clusters obtained are homogeneous inside, but heterogeneous between them.

In our study, the clusters were constructed for variables (influential factors and their elements and sub-elements) and the groups obtained are homogenous and independent. After several simulations, the clusters were finally designed using the Centroid clustering method, considering as measure the Simple Matching (as the variables are all binary). The distance between two clusters is computed with this method as the sum of distances between cluster's means for all the variables. A merged cluster has as a centroid a weighted combination of the two clusters that form it.

In relation to the objectives of our research, the cluster analysis presents the relationships between the elements and sub-elements of the 6 factor groups and allows us to observe the reasons behind the evolution of public accounting and the extent to which certain environmental factors influenced this evolution. In order to interpret them, the findings of the cluster analysis are correlated with the elements of public accounting history presented in section 3.1 .

Data was analyzed using the SPSS 19.0 statistical software. The 44 binary variables were considered the main factors able to influence changes in a public accounting system. A $45^{\text {th }}$ variable was introduced more as a control variable. This is the variable called "change" that shows whether or not in a certain period of time the Romanian accounting system has changed. From the results, we chose to present the dendogram (Fig. 1).

As the dendogram reveals, three major clusters have been identified during the optimum distance revealed by the analysis.

The first cluster is the largest one, compiling 23 out of the 45 analyzed variables. Within the political factors, we notice a dynamic political structure (multiple party systems), occurring in a democratic framework, enlivened by important political events (change of government, system reforms). In the same time, all legal factors are included in this group. At a macroeconomic level, the right to private property over goods, next to economic ascension enables a beneficial stability on a microeconomic level, manifested through typical elements of the market economy, where the activity of small and middle enterprises based on competition principles is sustained by internal and external financial sources. The group of socio-cultural factors is highly represented through the impact of social protection forms, respectively through the access and the trust that the state and population has to/in public information. All the variables that are related to the Romanian education system - free access to pre-university and university education are a guarantee of the education system's functioning.

The analysis of the first cluster brings forward the idea that the progress of public accounting history is under the influence of political, legal, economic, socio-cultural and educational factors. The establishment of a multi-party state that acts based on democratic principles, through the reforms it imposes, tries to connect to international tendencies with the simultaneous obligation of keeping the national specific. In such an environment, the legal factors group marks the evolution of public accounting by 
creating a legal framework through which the macro and micro economic system can ensure the stability of the national economy engine. The users of accounting information are the main reference for accounting progress. The transparency and the trust given to accounting information are socio-cultural factors with a vital effect on accountancy. The education system has a dual role. On the one hand, it coordinates the development of accounting taking into consideration the needs of the national economy and the complex process of its harmonization and convergence to international standards. On the other hand, through the common input of accounting theory and practice, education specialists are teaching graduates who later on ensure the optimum trend of Romanian public accounting evolution.

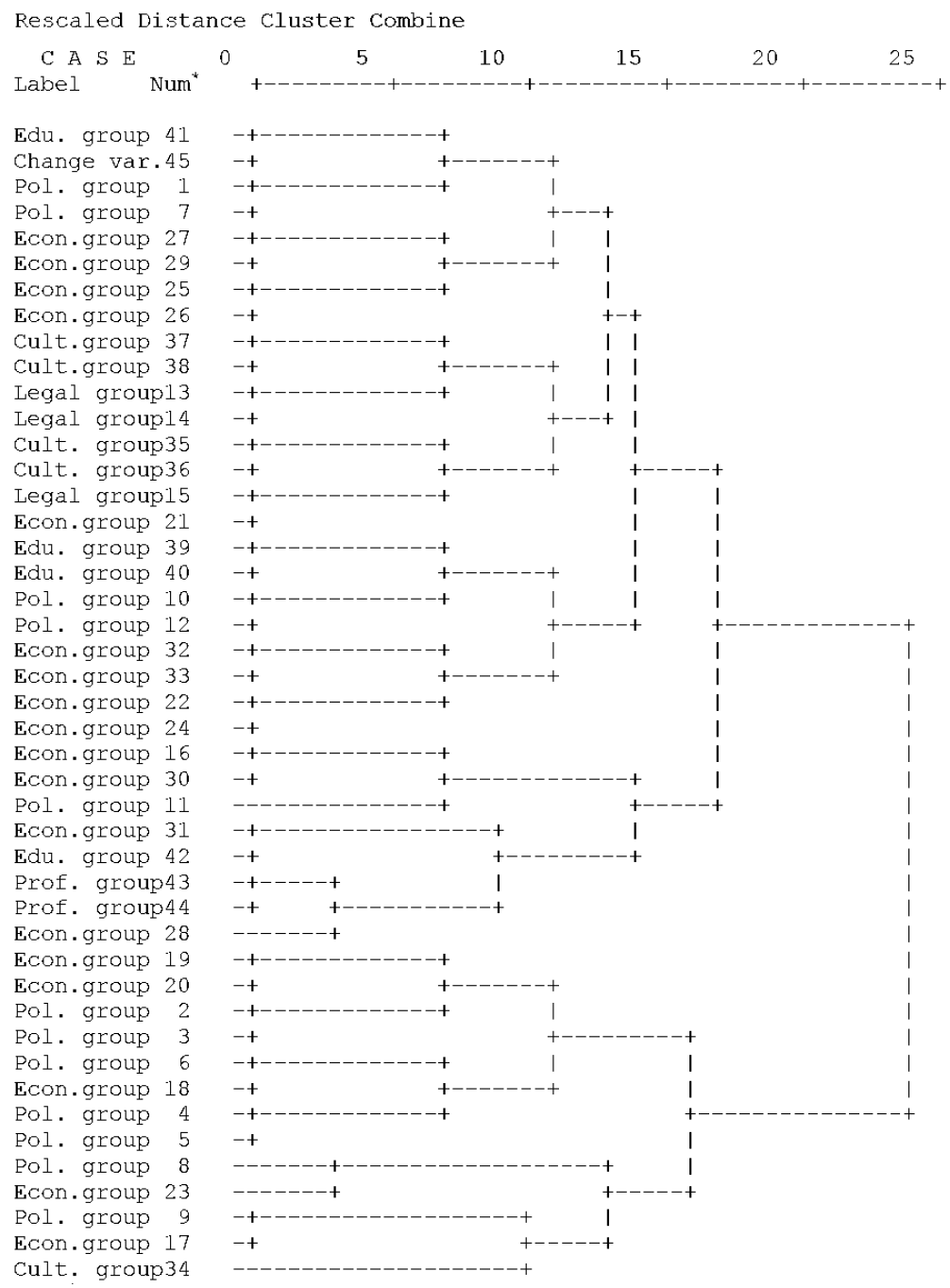

Fig. 1. Dendogram of the variables (Centroid method)

Note: * the number represents the influential factor (elements or sub elements) according to Appendix. 
The second cluster includes: political factors, in a more restricted form, where only one political event is in sight (adhesion to international organizations); economic factors, dispersed between macro and microeconomic aspects, with an extremely narrow representation (of the capitalist economic system, internal financial sources, enterprise complexity - national and multinational corporations); educational factors, restricted to the influence of the literature and the profession factors of which influence is significant for this cluster through its recognition and inclusion in a professional body.

Within the second cluster, the professional factor group is distinguished. Its influence on accounting evolution may be explained through the power of decision held by accounting specialists in relation to the applied procedures and enforced legal framework.

In the third cluster, the political factors are represented by the political structure, communist political system type and political events (war, unification). The macroeconomic aspects are significant in economic factors. The socio-cultural factors like change in lifestyle may influence the public accounting progress through the perception over the value of accounting information, its content, coherence, freedom and transparency.

A significant number of the political factors are noted in the third cluster. Associating these with macroeconomic influential factors is justified by the capacity of annihilating the microeconomic factors by a communist totalitarian political regime where socialist economy equals solely public property and interest. Accounting information serves the macro and direct control of the economy. Also, the association between the political factors and the profession group within this cluster proves that accounting evolution is influenced at several points in time by political decisions. In 1951, the communist regime decided to dissolve CECCAR. Thus, the accounting profession was felt with an advisory role, while the actual decisions were made based on entirely different considerations.

\section{Conclusions}

The objectives proposed in this study can be symbolized by the structure of a pyramid whose base are the phases of the Romanian public accounting system throughout its existence, from its early stages (1831) until now. At an intermediate level, using a historiography approach we identified elements and sub-elements of political, legal, economic, cultural educational and professional influential factors for each accounting phases. The top of the pyramid reveals the power of influential factors, respectively their interconnection, making up influence clusters.

Our research firstly confirms some of the results in the literature regarding accounting system environmental factors. Moreover, by determining a specific framework, the research singularizes the identified factor groups and develops elements and sub-elements for an emergent context and for public accounting. The periodization proposed by the study for the analyzed period is another theoretical implication.

Secondly, the study is a benchmark for assessing how the analyzed influential factors outlined the evolution of the Romanian public accounting system. The research could represent a useful reference to other CEE countries which until recently were under 
communist tutelage, and are considered today emerging countries. This is because international integration takes a lot of specific historical, economic, cultural and political past with its characteristics.

The cluster analysis conducted created an aggregation of factors. The existence of a democratic political system provides the possibility of molding public accounting by the need of a market economy in which the legal coordinates meet the users' needs and are governed by professional principles. This accounting progress is typical of some relatively large periods from the studied time span (1831-1943, 1989-present). The banking system variable affected the progress of the Romanian public accounting system from an independent position, without any connection to the other variables. The historical period between 1989-2011 is most adequate for the public accounting system in which the main influence comes from accountancy. Relating to international benchmarks and creating an ethical framework are guiding lines in the profession's progress and for accounting as a whole. Linking national needs to international realities is also present in other aspects (the adhesion to different international organizations, the capitalist economic system type, national and multinational corporations). Other results confirm that the role of accounting is far from being apolitical. Typical to the communist era (1944-1988), the decisions were made preeminently on political criteria. The political structure and political system established the opening or isolation from others and involvement, cooperation and restraint in the face of the change imposed by international realities, achieving or not the reforms that meet the needs and support the actual trends of reporting.

We believe that the study can be improved by enlarging the scope of comparison with other CEE countries, former members of the Communist system, in order to determine internationally, the degree of economic, political, cultural factors' influence. Further research is advisable in the direction of exclusive cultural factors' influence on the public accounting sector's evolution, based on acknowledged studies or performing a classification of influential factors to substantiate the explanation of differences between accounting systems. Finally, the investigation was conducted within a single country, thus narrowing the international relevance of its results.

\section{References}

Albu, C. N.; Albu, N.; Alexander, D. 2013. When global accounting standards meet the local context - insights from an emerging economy, Critical Perspectives on Accounting [online], [cited 02 February 2013]. Available from Internet: http://business.cf.ac.uk/sites/.../Final_Version_IPA_Paper_Reference_70.docx

Alexander, D.; Archer, S. (Eds.). 2001. European accounting guide. New York: Aspen Law\&Business.

Aubert, F.; Grudnitski, G. 2011. The impact and importance of mandatory adoption of International financial reporting standards in Europe, Journal of International Financial Management and Accounting 22(1): 1-26. http://dx.doi.org/10.1111/j.1467-646X.2010.01043.x

Bengtsson, E. 2011. Repoliticalization of accounting standard setting - the IASB, the EU and the global financial crisis, Critical Perspectives on Accounting 22: 567-580.

http://dx.doi.org/10.1016/j.cpa.2011.04.001 
Bellanca, S.; Vandernoot, J. 2013. Belgian public accounting: evolution and compliance with IPSAS, International Advances in Economic Research 19(1): 79-81.

http://dx.doi.org/10.1007/s11294-012-9386-8

Bistriceanu, Gh. 1992. Finanţe generale [General finance]. Bucureşti: U.R.A.

Calu, D. A. 2005. Istorie si dezvoltare privind contabilitatea din Romania [History and development of Romanian accounting]. Bucuresti: Economica.

Carnegie, G. D.; Napier, C. J. 2002. Exploring comparative accounting literature, Accounting, Auditing and Accountability Journal 15(5): 689-718. http://dx.doi.org/10.1108/09513570210448966

Cheng, R. H. 1992. An empirical analysis of theories on factors influencing state government accounting disclosure, Journal of Accountancy and Public Policy 11(1): 1-42.

http://dx.doi.org/10.1016/0278-4254(92)90013-N

Choi, F.; Mueller, G. 1984. International accounting. New Jersey: Prentice-Hall.

Constantiniu, F. 1997. O istorie sinceră a poporului roman [An honest history of the Romanian people]. Bucureşti: Universul Enciclopedic.

Deaconu, A.; Nistor, C.; Filip, C. 2009. The effect of transiting from cash accounting to accrual accounting on performance in the public sector, Studia Oeconomica 2: 115-128.

Demetrescu, C. G. 1972. Istoria contabilitatii [Accounting History]. Bucuresti: Didactica si Pedagogica.

Evans, J. H.; Patton, J. M. 1987. Signaling and monitoring in public-sector accounting, Journal of Accounting Research 25(Suppl.): 130-158. http://dx.doi.org/10.2307/2491083

Evian, I. N. 1946. Contabilitatea dublă [Bookkeeping by double entry]. Bucureşti: U. R. A.

Ezzamel, M.; Xiao, J. 2011. Accounting in transitional and emerging market economies, European Accounting Review 20(4): 625-37. http://dx.doi.org/10.1080/09638180.2011.629798

Farag, H.; Hommel, U.; Witt, P.; Wright, M. 2004. Contracting, monitoring, and exiting venture investments in transitioning economies: a comparative analysis of Eastern European and German markets, Venture Capital 6(4): 257-282. http://dx.doi.org/10.1080/1369106042000258490

Frank, W. G. 1979. An empirical analysis of international accounting principles, Journal of Accounting Research 17(2): 593-605. http://dx.doi.org/10.2307/2490520

Gastil, R. D. 1978. Freedom in the world-political rights and civil liberties. NY: Freedom House.

Gray, S. J. 1988. Towards a theory of cultural influence on the development of accounting systems internationally, Abacus 24(1): 1-15. http://dx.doi.org/10.1111/j.1467-6281.1988.tb00200.x

Hoque, Z.; Hopper, T. 1994. Rationality, accounting and politics: a case study of management control in a Bangladeshi jute mill, Management Accounting Research 5(1): 5-30.

http://dx.doi.org/10.1006/mare.1994.1002

Johnson, R. A.; Wichern, D. W. 1982. Classification and grouping techniques, in Applied Multivariate Statistical Analysis. New Jersey: Prentice-Hall.

Kajsiu, B. 2010. Down with politics! The crisis of representation in post-communist Albania, East European Politics \& Societies 24(2): 229-253. http://dx.doi.org/10.1177/0888325409354354

Laswad, F.; Fisher, R.; Oyelere, P. 2005. Determinants of voluntary web financial reporting by local government authorities, Journal of Accounting and Public Policy 24(2): 101-121.

http://dx.doi.org/10.1016/j.jaccpubpol.2004.12.006

Mueller, G. G. 1967. International accounting. Part I, New York: Macmillan.

Nachescu, M. L. 2010. Report on the development of the audit profession in Balkans after 1990, in 2nd Conference of Balkans and Middle Eastern Countries, 15-18 September 2010, Istanbul, Turkey. 
Nair, R. D.; Frank, W. G. 1980. The impact of disclosure and measurement practices on international accounting classifications, The Accounting Review LV(3): 426-450.

Nistor, C. S.; Sucala, L.; Matis, D.; Ienciu, A. 2008. The evolution of public accounting in Romania in the post-communist period, in 12th World Congress of Accounting Historians, 20-24 July 2008, Istanbul, Turkey.

Nobes, C. 1984. International classification of financial reporting. London: Croom Helm.

Nobes, C. 1998. Towards a general model of the reasons for international differences in financial reporting, Abacus 34(2): 162-187. http://dx.doi.org/10.1111/1467-6281.00028

Nobes, C. W.; Parker, R. H. 1985. Comparative international accounting. Oxfort: Phillip Allan. Pitulice, I. C. 2013. Accrual accounting adoption in the Romanian public sector, Romanian Statistical Review 1: 66-76.

Puxty, A. G.; Willmot, H. C.; Cooper, D. J.; Lowe, T. 1987. Modes of regulation in advanced capitalism: locating accounting in four countries, Accounting, Organizations and Society 12(3): 273-292. http://dx.doi.org/10.1016/0361-3682(87)90041-9

Radebaugh, L. H.; Gray, S. J. 1997. International accounting and multinational enterprises. New York: John Wiley \& Sons Inc.

Rezaee, Z. 1998. Studies in accounting history: tradition and innovation for the twenty-first century, Atlantic Economic Journal 26(2): 214-221. http://dx.doi.org/10.1007/BF02299363

Rusu, D.; Voina, D.; Cuciureanu, T.; Petri, R.; Man, V.; Niculiciuiu, C.; Horomnea, E. 1991. Fra Luca di Borgo şi doctrinele contabilităţii în cultura românească [Fra Luca di Borgo and accounting doctrines in Romanian culture]. Iaşi: Junimea.

Schmalenbach, E. 1927. Der kontenrahmen [Accounting system], Zeitschrift für Handelswissenschaftliche Forschung 21: 385-402.

Schroll, R. 1995. The new accounting system in the Czech Republic, European Accounting Review 4(4): 827-832. http://dx.doi.org/10.1080/09638189500000052

Ungureanu, I. C.; Ersoz, F. 2010. Commonalities and disparities among the EU candidate, Journal for Economic Forecasting 3: 173-186.

Zhang, G. 2005. Environmental influence on accounting development [online], [cited 23 January 2013]. Available from Internet: http://publishing.eur.nl/ir/repub/asset/1888/Chapter\%202.doc 


\section{APPENDIX}

Influential factors of historical phases in Romanian public accounting

\begin{tabular}{|c|c|c|c|c|c|c|c|c|c|c|c|}
\hline \multirow[b]{2}{*}{ No } & & \multicolumn{7}{|c|}{ Historical phases } & \multicolumn{3}{|c|}{ Clusters } \\
\hline & & $\begin{array}{c}1831- \\
1858\end{array}$ & $\begin{array}{c}1859- \\
1907\end{array}$ & $\begin{array}{c}1908- \\
1943\end{array}$ & $\begin{array}{c}1944- \\
1988\end{array}$ & $\begin{array}{l}1989- \\
2001\end{array}$ & $\begin{array}{c}2002- \\
2005\end{array}$ & $\begin{array}{c}2006- \\
2011\end{array}$ & 1 & 2 & 3 \\
\hline I & \multicolumn{11}{|c|}{ Political factors group } \\
\hline & Political structure & & & & & & & & & & \\
\hline 1 & Multiple party systems & 0 & 1 & 1 & 0 & 1 & 1 & 1 & $\mathrm{X}$ & & \\
\hline 2 & Dominant party systems & 0 & 0 & 0 & 0 & 0 & 0 & 0 & & & $\mathrm{X}$ \\
\hline 3 & One party systems & 0 & 0 & 0 & 1 & 0 & 0 & 0 & & & $\mathrm{X}$ \\
\hline 4 & Military party system & 0 & 0 & 0 & 0 & 0 & 0 & 0 & & & $\mathrm{X}$ \\
\hline 5 & $\begin{array}{l}\text { Traditional princedoms } \\
\text { Politic system type }\end{array}$ & 1 & 0 & 0 & 0 & 0 & 0 & 0 & & & $\mathrm{X}$ \\
\hline 6 & Communism & 0 & 0 & 0 & 1 & 0 & 0 & 0 & $\mathrm{X}$ & & $\mathrm{X}$ \\
\hline 7 & $\begin{array}{l}\text { Democracy } \\
\text { Political events }\end{array}$ & 1 & 1 & 1 & 0 & 1 & 1 & 1 & & & \\
\hline 8 & War & 0 & 0 & 1 & 0 & 0 & 0 & 0 & & & $\mathrm{X}$ \\
\hline 9 & $\begin{array}{l}\text { Regions unifications/ New } \\
\text { state appearance }\end{array}$ & 0 & 1 & 1 & 0 & 0 & 0 & 0 & & & $\mathrm{X}$ \\
\hline 10 & Government change & 0 & 1 & 1 & 1 & 1 & 1 & 1 & $\mathrm{X}$ & & \\
\hline 11 & $\begin{array}{l}\text { Membership organizations } \\
\text { (EU, NATO, regional } \\
\text { organizations) }\end{array}$ & 0 & 0 & 0 & 0 & 0 & 1 & 1 & & $X$ & \\
\hline 12 & $\begin{array}{l}\text { System reforms (agrarian, tax, } \\
\text { education and other reforms) }\end{array}$ & 1 & 1 & 1 & 1 & 1 & 1 & 1 & $X$ & & \\
\hline II & & & Legal fa & ctors $g$ & oup & & & & & & \\
\hline 13 & Public accounting legislation & 0 & 1 & 1 & 1 & 1 & 1 & 1 & $\mathrm{X}$ & & \\
\hline 14 & Civil law & 1 & 1 & 1 & 1 & 1 & 1 & 1 & $\mathrm{X}$ & & \\
\hline 15 & Tax legislation & 0 & 1 & 1 & 1 & 1 & 1 & 1 & $\mathrm{X}$ & & \\
\hline
\end{tabular}


Continue of Appendix

\begin{tabular}{|c|c|c|c|c|c|c|c|c|c|c|c|}
\hline \multirow[b]{2}{*}{ No } & & \multicolumn{7}{|c|}{ Historical phases } & \multicolumn{3}{|c|}{ Clusters } \\
\hline & & $\begin{array}{c}1831- \\
1858\end{array}$ & $\begin{array}{c}1859- \\
1907\end{array}$ & $\begin{array}{c}1908- \\
1943\end{array}$ & $\begin{array}{c}1944- \\
1988\end{array}$ & $\begin{array}{c}1989- \\
2001\end{array}$ & $\begin{array}{c}2002- \\
2005\end{array}$ & $\begin{array}{c}2006- \\
2011\end{array}$ & 1 & 2 & 3 \\
\hline III & \multicolumn{11}{|c|}{ Economic factors group } \\
\hline & $\begin{array}{l}\text { A. Macroeconomic aspects } \\
\text { Economic system type }\end{array}$ & & & & & & & & & & \\
\hline 16 & Capitalist & 0 & 0 & 0 & 0 & 1 & 1 & 1 & & $\mathrm{X}$ & \\
\hline 17 & Capitalist statist & 0 & 1 & 1 & 0 & 0 & 0 & 0 & & & $\mathrm{X}$ \\
\hline 18 & Socialist capitalist & 0 & 0 & 0 & 0 & 0 & 0 & 0 & & & $\mathrm{X}$ \\
\hline 19 & $\begin{array}{l}\text { Socialist } \\
\text { Ownership values }\end{array}$ & 0 & 0 & 0 & 1 & 0 & 0 & 0 & & & $X$ \\
\hline 20 & Public & 0 & 0 & 0 & 1 & 0 & 0 & 0 & & & $\mathrm{X}$ \\
\hline 21 & $\begin{array}{l}\text { Private } \\
\text { Stage of economic } \\
\text { development (macro aspect) }\end{array}$ & 1 & 1 & 1 & 0 & 1 & 1 & 1 & $\mathrm{X}$ & & \\
\hline 22 & Economic growth & 0 & 1 & 1 & 1 & 1 & 1 & 1 & $\mathrm{X}$ & & \\
\hline 23 & Economic recession & 1 & 0 & 1 & 1 & 0 & 0 & 1 & & & $\mathrm{X}$ \\
\hline 24 & $\begin{array}{l}\text { Existence of a banking system } \\
\text { B. Microeconomic aspects } \\
\text { Stage of economic } \\
\text { development (micro aspect) }\end{array}$ & 0 & 1 & 1 & 1 & 1 & 1 & 1 & & & \\
\hline 25 & Competition & 1 & 1 & 1 & 0 & 1 & 1 & 1 & $\mathrm{X}$ & & \\
\hline 26 & $\begin{array}{l}\text { Commercial advertisement } \\
\text { Sources of financing }\end{array}$ & 1 & 1 & 1 & 1 & 1 & 1 & 1 & $\mathrm{X}$ & & \\
\hline 27 & - Internal (state) & 1 & 1 & 1 & 1 & 1 & 1 & 1 & $\mathrm{X}$ & & \\
\hline 28 & - Internal (investors) & 0 & 0 & 1 & 0 & 1 & 1 & 1 & & $\mathrm{X}$ & \\
\hline 29 & $\begin{array}{l}\text { - External (foreign loans or } \\
\text { international funds refundable/ } \\
\text { non-refundable) } \\
\text { Enterprise complexity }\end{array}$ & 0 & 1 & 1 & 1 & 1 & 1 & 1 & $\mathrm{X}$ & & \\
\hline 30 & National corporation & 0 & 0 & 0 & 0 & 1 & 1 & 1 & & $\mathrm{X}$ & \\
\hline 31 & $\begin{array}{l}\text { Multinational corporation } \\
\text { Big enterprise }\end{array}$ & 0 & 0 & 1 & 0 & 1 & 1 & 1 & & $\mathrm{X}$ & \\
\hline 32 & Small and medium enterprises & 0 & 1 & 1 & 1 & 1 & 1 & 1 & $\mathrm{X}$ & & \\
\hline 33 & (SMEs) & 1 & 1 & 1 & 1 & 1 & 1 & 1 & $\mathrm{X}$ & & \\
\hline IV & & Soc & o-Cultur & al factor & rs group & & & & & & \\
\hline 34 & $\begin{array}{l}\text { Lifestyle changes } \\
\text { (allotment, expropriation) } \\
\text { Forms of social protection }\end{array}$ & 0 & 1 & 0 & 1 & 1 & 0 & 0 & & & $\mathrm{X}$ \\
\hline 35 & $\begin{array}{l}\text { Free access to information } \\
\text { Confidence in public }\end{array}$ & 0 & 1 & 1 & 1 & 1 & 1 & 1 & $\mathrm{X}$ & & \\
\hline 36 & $\begin{array}{l}\text { Information (disclosure of } \\
\text { financial statements, revenues } \\
\text { and expenditures budget, } \\
\text { audit) }\end{array}$ & 0 & 1 & 1 & 0 & 1 & 1 & 1 & $\mathrm{X}$ & & \\
\hline 37 & - Medium/ High level & 0 & 1 & 1 & 0 & 1 & 1 & 1 & & & \\
\hline 38 & - Small level & 1 & 0 & 0 & 1 & 0 & 0 & 0 & $\mathrm{X}$ & & $\mathrm{X}$ \\
\hline
\end{tabular}


End of Appendix

\begin{tabular}{|c|c|c|c|c|c|c|c|c|c|c|}
\hline \multirow[b]{2}{*}{ No } & & \multicolumn{7}{|c|}{ Historical phases } & \multicolumn{2}{|c|}{ Clusters } \\
\hline & & $\begin{array}{c}1831- \\
1858\end{array}$ & $\begin{array}{c}1859- \\
1907\end{array}$ & $\begin{array}{c}1908- \\
1943\end{array}$ & $\begin{array}{c}1944- \\
1988\end{array}$ & $\begin{array}{l}1989- \\
2001\end{array}$ & $\begin{array}{c}2002- \\
2005\end{array}$ & $\begin{array}{c}2006- \\
2011\end{array}$ & 1 & 23 \\
\hline $\mathrm{V}$ & \multicolumn{10}{|c|}{ Education factors group } \\
\hline 39 & $\begin{array}{l}\text { Economic university } \\
\text { system }\end{array}$ & 0 & 1 & 1 & 1 & 1 & 1 & 1 & $\mathrm{X}$ & \\
\hline 40 & $\begin{array}{l}\text { Economic pre university } \\
\text { system }\end{array}$ & 1 & 1 & 1 & 1 & 1 & 1 & 1 & $\mathrm{X}$ & \\
\hline 41 & Free access to education & 0 & 1 & 1 & 1 & 1 & 1 & 1 & $\mathrm{X}$ & \\
\hline 42 & Specialized publications & 1 & 1 & 1 & 1 & 1 & 1 & 1 & & $\mathrm{X}$ \\
\hline VI & \multicolumn{10}{|c|}{ Profession factors group } \\
\hline 43 & $\begin{array}{l}\text { Existence of the accounting } \\
\text { profession }\end{array}$ & 0 & 0 & 1 & 1 & 1 & 1 & 1 & & $X$ \\
\hline 44 & $\begin{array}{l}\text { Existence of an accounting } \\
\text { professional body }\end{array}$ & 0 & 0 & 1 & 0 & 1 & 1 & 1 & & $X$ \\
\hline
\end{tabular}

Source: Authors projection based on Gastil (1978), Choi and Mueller (1984), Nobes (1984), Radebaugh and Gray (1988), Gray (1997), Zang (2005).

Cristina Silvia NISTOR is Associate Professor at Babes-Bolyai University in Cluj-Napoca. She is currently teaching undergraduate and master courses in Public Accounting, International Accounting Standards for Public Sector and Project Evaluation. Her domains of competence are public sector accounting and international references in this field.

Adela DEACONU is Associate Professor at Babes-Bolyai University in Cluj-Napoca. She is currently teaching undergraduate and master courses in Accounting, Business Valuation and Financial Diagnosis at Babeş-Bolyai University in Cluj-Napoca and is associate lecturer at CNAM Paris and ASE Bucharest MBA. Her research areas of interest are international accounting and financial reporting valuations.

Codruta MARE is Lecturer (UK)/ Assistant Professor at Babes-Bolyai University in Cluj-Napoca. She is currently teaching undergraduate and master courses in Spatial Econometrics, Economic Forecasting, Demography and Descriptive Statistics at Babeş-Bolyai University in Cluj-Napoca. Her research areas of interest are spatial analysis, forecasting and time series analysis, European integration, demography, education, econometric analysis. 